\title{
Update of the EMHG database on genetic variants in type 1 ryanodine receptor and their possible impact on phenotype
}

\author{
Florian Grütter ${ }^{*}$, Thierry Girard ${ }^{2}$ \\ From 33rd Annual Meeting of the European Malignant Hyperthermia Group (EMHG) \\ Würzburg, Germany. 15-17 May 2014
}

\section{Background}

The type 1 ryanodine receptor (RYR1) is expressed in human skeletal muscle and plays a key role in calcium homeostasis. Most patients with malignant hyperthermia $(\mathrm{MH})$ have mutations in the RYR1 gene.

Today, the gold standard for $\mathrm{MH}$ diagnosis is an invasive open muscle biopsy followed by the in-vitro-contracture-test (IVCT). Less invasive diagnosis using molecular genetic methods is of increasing importance, but knowledge about genetic variants in RYR1 is limited. The European MH Group (EMHG) RYR1 mutation database is not up-to-date and lacks information on a significant number of more recently identified variants or further knowledge on variants already in the database. Therefore, the need for an update in order to expand the use of molecular genetic testing is required.

The aim of this study was to collect information about variants in the RYR1 gene and their functional effect. Finally this information will be imported into the EMHG RYR1 mutation database.

\section{Materials and methods}

PubMed was used for data collection. For the search, the three keywords "Malignant Hyperthermia", "Mutation" and "Ryanodine Receptor Calcium Release Channel" were used; the operator was "AND". Publication dates from the beginning of 2006 to the end of 2012 were selected. However, some older and newer studies were also included if they seemed important for the gain of information. Additionally, the considered papers had to be relevant for the human species. The software EndNote X7 (Thomson Reuters, Carlsbad, CA, USA) was used for administration of references and data was collected and processed in Microsoft Excel for Mac 2011 (Microsoft Corporation, Redmont, WA, USA).

\section{Results}

Altogether 62 publications were found according to the search algorithm. In the newly created database, an overall of 316 variants were gathered. 143 variants were not yet in the EMHG database, 129 of them not functionally

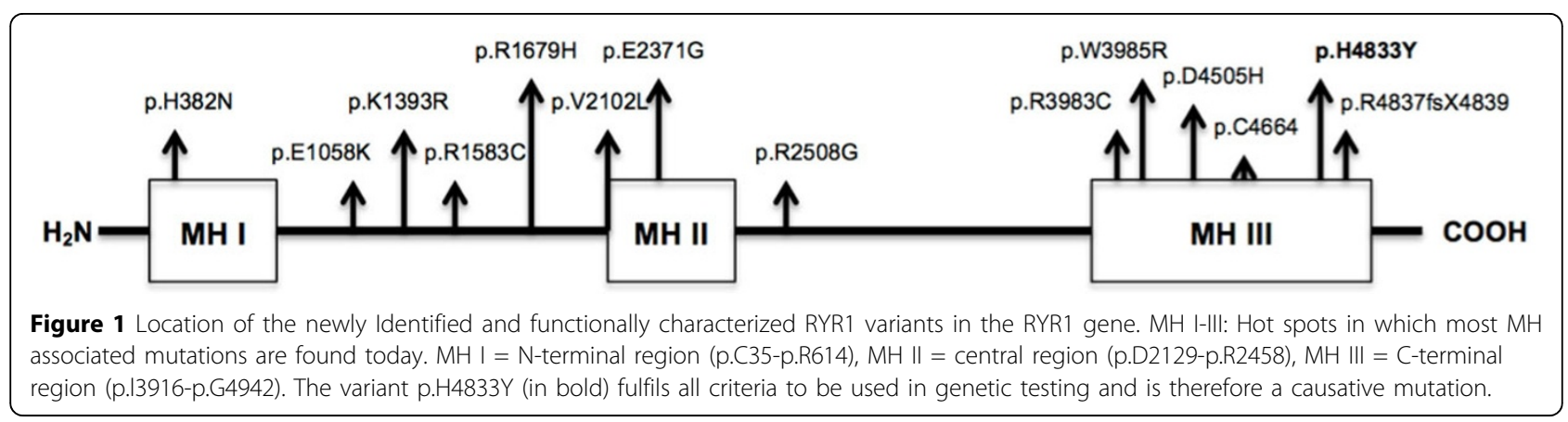

${ }^{1}$ University of Basel, Basel, 4003, Switzerland

Full list of author information is available at the end of the article

C 2014 Grütter and Girard; licensee BioMed Central Ltd. This is an Open Access article distributed under the terms of the Creative Commons Attribution License (http://creativecommons.org/licenses/by/4.0), which permits unrestricted use, distribution, and reproduction in any medium, provided the original work is properly cited. The Creative Commons Public Domain Dedication waiver Biomed Central (http://creativecommons.org/publicdomain/zero/1.0/) applies to the data made available in this article, unless otherwise stated. 
characterized or non-pathogenic, 13 functionally characterized and putatively causative and one causative (p.H4833Y), respectively.

Among another 11 variants which were already in the EMHG database two (p.R530H, p.R2336H) can be classified as causative (Figure 1).

\section{Conclusions}

This study shows that important additional information on variants in RYR1 was published since 2006. However, only three mutations (p.R530H, p.R2336H and p.H4833Y) can be newly classified as causative mutations according to the EMHG guidelines. The main reason for this disappointing conclusion is the fact that the criterion "cosegregation with the disease in at least two pedigrees" according to the EMHG guidelines was missing in otherwise $\mathrm{MH}$ causative mutations. Nevertheless, this update of the database gives easier access to genetic information and emphasizes the increasing significance of genetic testing.

Authors' details

'University of Basel, Basel, 4003, Switzerland. ${ }^{2}$ Department of Anesthesia, University Hospital of Basel, Basel, 4031, Switzerland.

Published: 18 August 2014

doi:10.1186/1471-2253-14-S1-A12

Cite this article as: Grütter and Girard: Update of the EMHG database on genetic variants in type 1 ryanodine receptor and their possible impact on phenotype. BMC Anesthesiology 2014 14(Suppl 1):A12.
Submit your next manuscript to BioMed Central and take full advantage of:

- Convenient online submission

- Thorough peer review

- No space constraints or color figure charges

- Immediate publication on acceptance

- Inclusion in PubMed, CAS, Scopus and Google Scholar

- Research which is freely available for redistribution

Submit your manuscript at www.biomedcentral.com/submit 